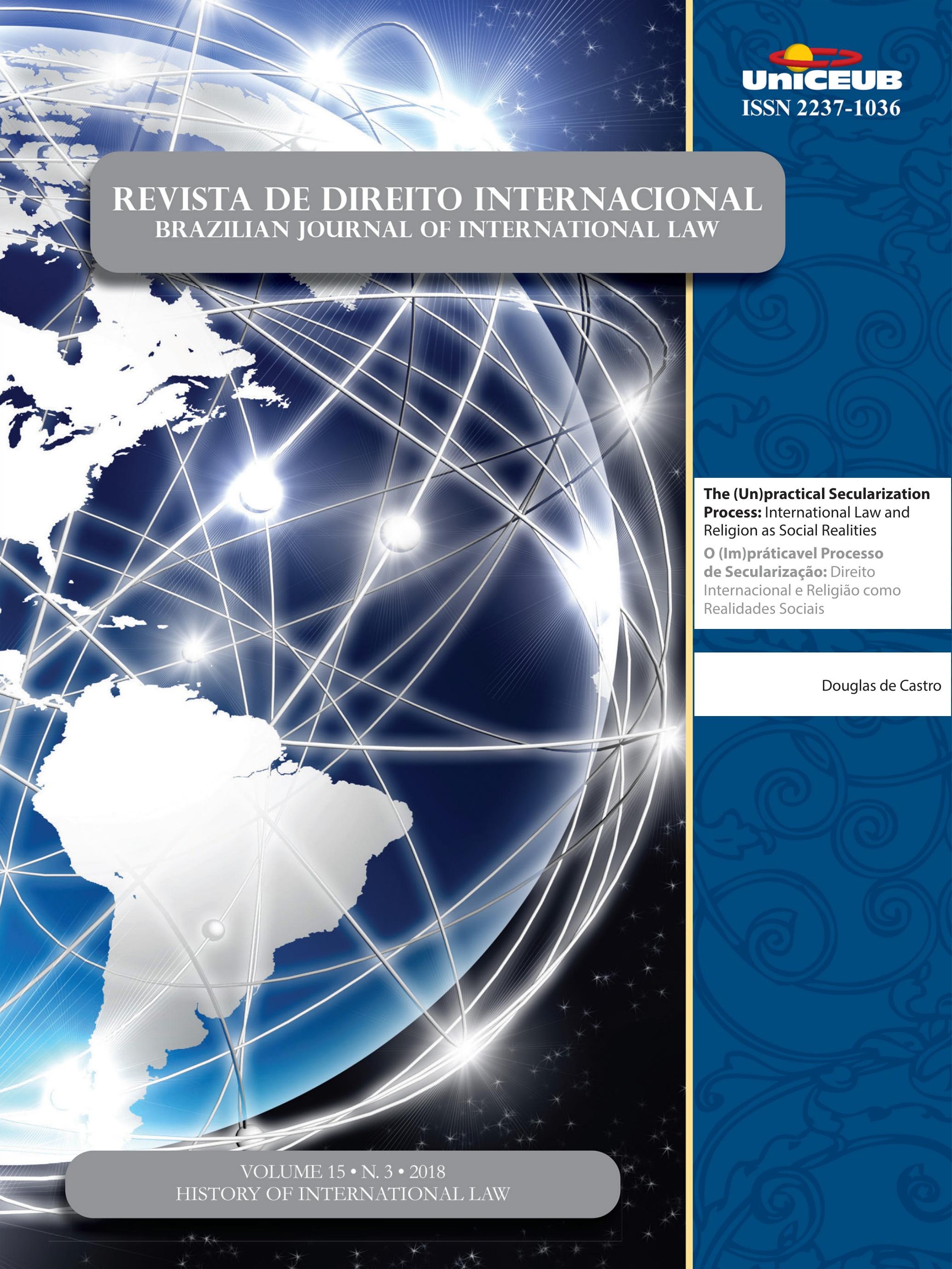




\section{Sumário}

I. Dossiê Especial: History of International Law ...................................1

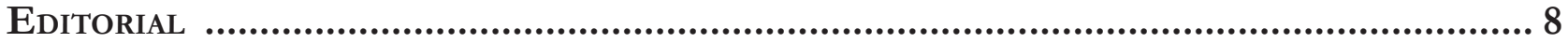

What does it mean to apply history in international law studies? ....................................................... 8

Arthur Roberto Capella Giannattasio

SuR LA NATURE DU Droit ISLAMIQUe............................................................................14

Hocine Benkheira

Islamic Shari’a Law, History and Modernity: Some Reflections .................................25 Suleiman A. Mourad

The (Un)practical Secularization Process: International Law and Religion as So-

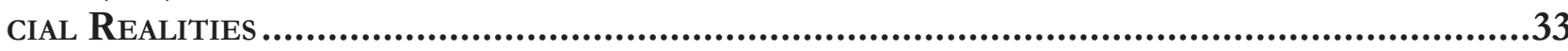

Douglas de Castro

BRAZILIAN LITERATURE ON INTERNATIONAL LAW DURING THE EMPIRE REGIME. OR THE DIFFUSION OF INTERNATIONAL LAW IN THE PERIPHERIES THROUGH APPROPRIATION AND ADAPTATION.

Airton Ribeiro da Silva Júnior

Natural, POSitivo, romano E Universal? INVESTigaÇão SObre O Direito das GENTES EM

Tomás de Aquino

Rafael Zelesco Barretto

II. Artigos sobre outros temas

VINCULAÇÃO DOS DIREITOS ECONÔMICOS, SOCIAIS E CULTURAIS: UMA DISCUSSÃO DO DESENVOLVImento humano com base no conceito de Amartya Sen sobre o mínimo existencial.....99

Natalia Mascarenhas Simões Bentes e Yasmim Salgado Santa Brígida

A NOVA LeI de MigraÇão E A PROTEÇão CONFERIDA AO APÁtrida: ALINHAMENTO BRASILEIRO AO PADRÃO INTERNACIONAL DE DIREITOS HUMANOS

Pedro Henrique de Faria Barbosa e Sylvio Loreto

E se o Supremo Tribunal Federal (STF) restabelecer a vigência da Convenção n. 158 
da Organização Internacional do Trabalho (OIT) na ordem Jurídica brasileira? SoBRE UMA POSSÍVEL REVIRAVOLTA, PELA VIA DO DIREITO INTERNACIONAL, DAS LEIS TRABALHISTAS BRASILEIRAS 138

Daniel Damasio Borges

JULGADOS DA CORTE INTERAMERICANA SOBRE CASOS BRASILEIROS E POLÍTICAS PÚBLICAS: REFLEXÕES ACERCA DE POSSÍVEIS INFLUIÇÕES 165

Rafael Osvaldo Machado Moura

CREATING BRIDGES BETWEEN INTERNATIONAL RELATIONS THEORY AND INTERNATIONAL HUMAN RIGHTS LAW: CONSTRUCTIVISM AND THE ROLE OF BRAZIL IN THE INTER-AMERICAN SYSTEM OF HUMAN RIGHTS 179

Ismael Francisco de Souza, Luciana Rocha Leme e Erick da Luz Scherf

Justiça de transição na Argentina e o Sistema Interamericano de Direitos Humanos: uMa ANÁlise do CASo Luis Muiña (“REgRa 2x1”) 199

Emilio Peluso Neder Meyer e Jessica Holl

A legalidade e legitimidade da INTERVEnÇão humanitÁria: UMA MEDIDA AINDA NECESSÁRIa.219 Natália Caye Batalha Boeira

O Acordo de Escazú E o ACESSo À INFORMaÇão AMbiental no Brasil. 252 Érica Bezerra Queiroz Ribeiro e Bruno Amaral Machado

Dos POVOS NATIVOS AO SURGIMENTO DOS MOVIMENTOS SOCIAIS: INFLUÊNCIAS DOS DISCURSOS JURÍDICOS, RELIGIOSOS E MÉDICOS PARA A CONSTRUÇÃO DO CONCEITO DE HOMOSSEXUALIDADE NO BRASIL .267 Bruno Rafael Silva Nogueira Barbosa e Robson Antão de Medeiros

Aspectos Jurídicos da PARTicipaÇão dA UNião Europeia NA OMC: COMPREENDENdo SUTILEZAS DE UM DELICADO ENLACE. 291

Camilla Capucio

Path to judicial activism? The use of "Relevant rules of international law" by the WTO Appellate Body

Mariana Clara de Andrade

LEVEZA E PESO NA MEDIAÇÃO COMERCIAL INTERNACIONAL: O CONTEÚDO JURÍDICO DO ACORDO CORPORATIVO MEDIADO E SUA INCORPORAÇÃo PELO DiREITO BRASILEIRO .324 Henrique Lenon Farias Guedes 
JURISDIÇÃO INTERNACIONAL E AS DIFICULDADES DE EXECUÇÃO DE SENTENÇAS INTERNACIONAIS NO BRASIL

Nevitton Vieira Souza

O DEVER DE COOPERAÇÃo NOS CONTRATOS DE VENDA INTERNACIONAL DE MERCADORIAS: PRESSUPOSTOS TEÓRICOS E REPERCUSSÕES PRÁTICAS DA CLÁUSULA GERAL DA BOA-FÉ OBJETIVA PARA A APLICAÇÃo DA CISG .358

Angelo Gamba Prata de Carvalho

A DiMENSÃo JURÍdiCA DO IMPERIALISMO NA (DES)ORDEM GLOBAL CAPITALISTA: UMA ANÁLISE COM BASE NA CRÍTICA MARXISTA AO DIREITO INTERNACIONAL E ÀS RELAÇÕES POLÍTICO-ECONÔMICAS DE DOMINAÇÃO E DEPENDÊNCIA.

Thomaz Delgado De David, Maria Beatriz Oliveira da Silva e Rosane Beatris Mariano da Rocha Barcellos Terra

A participaÇão de Brasil e Estados Unidos na formulação das regras multilaterais do

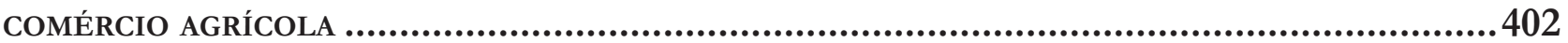

Vera Thorstensen, Vivian Daniele Rocha Gabriel e Alebe Linhares Mesquita

A galáxia lex e a construÇão de um Sistema jurídico transnacional ........................ 441

Eugênia Cristina Nilsen Ribeiro Barza e Jéssyka Maria Nunes Galvão

Has the Ability of Truth Commissions to Recommend Amnesty Been Effective in Enhancing Perpetrator Cooperation? 453 Jeremy Sarkin

A CONCEPTUAL PAPER ON THE POLICY-FRAMEWORK THAT MIRRORS THE DYNAMIC LINK BETWEEN Human Security, Social Protection and Safety Nets, and Food and Nutritional Security: The Case of the "Gulayan sa Paaralan Program", the Philippines.... 478 Renato Lagapa Base

INCENTIVISING SMALLHOLDER FARMER LIVELIHOODS AND CONSTRUCTING FOOD SECURITY THROUGH HOME-GROWN SCHOOL FEEDING: EVIDENCE FROM NORTHERN GHANA .491

Clement Mensah

Policy COHERENCE In THE IMPLEMENTATION OF THE 2030 AgENDA FOR SUSTAINABLE DEVELOpment: the Brazilian School Feeding Programme Case Study .506 Mariana Werlang Girardi 


\title{
The (Un)practical Secularization Process: International Law and Religion as Social Realities*
}

\author{
O (Im)práticavel Processo de Secularização: \\ Direito Internacional e Religião como \\ Realidades Sociais
}

Douglas de Castro**

\begin{abstract}
The long debate about separation of International law and religion might be traced since the Peace of Westphalia. However, empirical evidence shows that not only both have been closely connected ontologically but instrumental to each other to realize their objectives. This article applies the tenets of the social theory propagation approach: phenomenology and rhetoric to identify the links between international law and religion in history to identify the dialectic existence between them, and how unpractical is secularization as "preached" by mainstream academic considering the social realities experienced in both fields.
\end{abstract}

Keywords: International Law; Religion; Secularism; Phenomenology; Rhetoric; TWAIL

\section{Resumo}

O debate sobre a separação entre direito internacional e religião pode ser traçado desde a Paz de Vestfália. No entanto, evidências empíricas mostram não somente que ambos estão conectados ontologicamente, mas, instrumentais um ao outro para a atingir seus objetivos. Este artigo aplica os fundamentos da abordagem de propagação das teorias sociais: a fenomenologia e a retórica para identificar as ligações e dialética existentes entre o direito internacional e religião na história, demostrando como é impraticável a secularização como "pregada" pela academia considerando a realidade social vivenciada por ambos campos.

Palavras-chave: Direito Internacional; Religião; Secularismo; Fenomenologia; Retórica; TWAIL

** Post-Doc in International Economic Law - São Paulo Law School (FGV). PhD in Political Science - University of São Paulo (FFLCH-USP). Master's in law - University of São Paulo (FD-USP). LL.M. in International Law - J. Reuben Clark Law School (BYU). Visiting Scholar in the Foundation for Law and International Affairs (Washington D.C.). Professor of International Law and Relations in the Paulista University (UNIP). Researcher in the Global Law Center - São Paulo Law School (FGV). E-mail: douggcastro@gmail.com

* Recebido em: 30/09/2018 Aprovado em: 23/11/2018 


\section{INTRODUCTION}

The attack of the World Trade Center in 2001 by Al-Quaeda members made religion surface to the public debate. However, this unfortunate event skewed the discussion on two main issues: religious terrorism and Islam X West. More recently, the wave of migrants fleeing to Europe escaping countries in regional and international conflicts, such as Syria, exacerbates the debate.

Long before September 11, the debate over religious influences in the public arena were already in place due to the complementary role of faith-based organizations as providers of the public goods (in addition to the spiritual guidance) due to the sounding failure of some states around the world. As such, debates over the secularization become pivotal to understand the role of religion in local and international politics and the development of International Law.

The efforts to isolate the religious dimension from International Law is a project that initiates with the Enlightenment and coincides with the Peace of Westphalia in $1648 .{ }^{1}$ Westphalia represents the historical marker for the origin of modern order of states, which has ended the ancien régime based on the hierarchy in which at the top were the Pope and the figure of the Holy Roman Emperor, and the birth of a new era regarding the reach and contents of Internationa Law. ${ }^{2}$ It is the origin of the sovereign states as equals in the international system, not subject to a higher authority. The Westphalian treaty ended a long period of war in which the Catholics and Protestants fought to impose their religions on each other. ${ }^{3}$

According to Leo Grossman, the Peace of Westphalia $[\ldots]$ for better or worse, marks the end of an epoch and the opening of another. It represents the majestic portal which

1 The Peace of Westphalia is the name of the treaty that ended the Thirty Years War. For a complete account of the events that lead to war and its end, see: BAKER, H. W. H. Halleck's International Law, or Rules Regulating the Intercourse of States in Peace and War, Vol. 1. Forgotten Books, 2012.

2 HOLSTI, Kalevi J. Peace and War: Armed Conflicts and International Order, 1648-1989. Cambridge; New York: Cambridge University Press, 1991.

3 JANIS, Mark Weston. A Sampler of Religious Experiences in International Law. Rochester, NY: Social Science Research Network, 2008. Retrieved from: <https://papers.ssrn.com/ abstract $=1101749>$. Last Access: May 21, 2018. leads from the old into the new world. ${ }^{4}$ As observed in this utterance, Westphalia has usually viewed as a point in history that International Law emerges as a result of the Illuminist project in which reason replaces tradition and religion, thus, disregarding the typical movements of the historical processes such as heterogeneity, fragmentation, ruptures, and contingencies. ${ }^{5}$

In Davis Kennedy's essay Images of Religion in International Law, we found the objection to this static representation of the relationship between religion and International Law. For Kennedy, religion is inseparable from International Law, as the religion dimension $[\ldots]$ is something we used to have but not necessary whatsoeverfor theorizing modern International Law. ${ }^{6}$ As such, the construction and reproduction of the self-image of International Law is a pure exercise of reason by the aversion of its religious origin and influences, which is inconsistent with the social reality that both represent in the world today or to describe what Martti Koskenniemi called the esprit d'internationalité of our days.?

To that end, are the "Lights" making International professors and students blind? Is the secularism a mask to avoid a broader observation of International Law and its relationship with the "other" social realities and values?

Upon these initial considerations, we hypothesize that the secularization process of International Law as part of the non-linear process towards modernity represents a myth. ${ }^{8}$ International Law uses

4 VAGTS, Alfred; VAGTS, Detlev F. The Balance of Power in International Law: A History of an Idea. American Journal of International Law, v. 73, n. 4, p. 555-580, 1979. Retrieved from: <https://www. cambridge.org/core/journals/american-journal-of-internationallaw/article/div-classtitlethe-balance-of-power-in-international-lawa-history-of-an-ideadiv/0E85B738554D09B6FBD6267799F41 4B2>. Last Access: May 21, 2018. p.28.

5 KALMO, Hent; SKINNER, Quentin (Orgs.). Sovereignty in Fragments: The Past, Present and Future of a Contested Concept. Reprint edition. Cambridge: Cambridge University Press, 2014.

6 JANIS, Mark Weston. A Sampler of Religious Experiences in International Law. Rochester, NY: Social Science Research Network, 2008. Retrieved from: <https://papers.ssrn.com/abstract=1101749>. Last Access: May 21, 2018. p.145.

7 KOSKENNIEMI, Martti. The Gentle Civilizer of Nations: The Rise and Fall of International Law 1870-1960. Cambridge: Cambridge University Press, 2004.

8 "Myth is a type of speech" which, as part of semiotics, "has the task of giving a historical intention a natural justification, and making contingency appear eternal. The signifier of myth presents itself in an ambiguous way: it is at the same time meaning and form, full on one side and empty on the other. What is characteristic of myth? To transform a meaning into form. In other words, myth is always a 
the template of Religion for its construction and development. Therefore, the attempts to separate the religious dimension from International Law denies the commonly held assumptions and the unique and pervasive factors that exist in both, thus, making the separation incomplete and ambiguous as a theory and practice.

In methodological terms, in addition to the hypothetical-deductive method, we use the historical method combined with critical junctures to understand the consequences of the exacerbation of the secularization process in Internationa Law theorization. This paper relies on the Capoccia \& Kelemen's study on institutional critical junctures methodology to promote the macrohistorical analyses of the secularization process of International Law since Westphalia to our days, searching for patterns and regularities that might result in the confirmation empirically of the myth of secularization, identifying the phenomenology and rhetoric involved in this claim. ${ }^{?}$

The success of the claim of the secularisation of Internationa Law is due to " $[. .$.$] the idea that individuals$ organize the objects of their world not logically or empirically but 'phenomenologically, not according to the formal rules of thought or the nature of the object but according to their intentions." ${ }^{10}$

As grand temporal markers for the macrohistorical analysis, we use the periodization of the International Law developed by Janis \& Evans ${ }^{11}$ : before 1648; 1648 1918; and 1918 to present. This historical framework is used to localize the analysis of the relationship of international law and religion, and how ideas about it were shaped according to needs of the major players in the international system that emerged after Westphalia.

language-robbery." BARTHES, R. Mythologies (A. Lavers, Trad.). New York, NY: Farrar, Straus and Giroux, 1972, p. 142.

9 CAPOCCIA, Giovanni; KELEMEN, R. Daniel. The Study of Critical Junctures: Theory, Narrative, and Counterfactuals in Historical Institutionalism. World Politics, v. 59, n. 3, p. 341-369, 2007. Retrieved from: <https://www.cambridge.org/core/journals/world-politics/ article/the-study-of-critical-junctures-theory-narrative-andcounterfactuals-in-historical-institutionalism/BAAE0860F1F64135 7C29C9AC72A54758>. Last Access: Sept 21, 2018.

10 DAVIS, Murray S. "That's Classic!" The Phenomenology and Rhetoric of Successful Social Theories. Philosophy of the Social Sciences, v. 16, n. 3, p. 285-301, 1986. Retrieved from: <https://doi.org/10.1177/0 04839318601600301>. Last Access: Sept 21, 2018. p.156.

11 JANIS, Mark W.; EVANS, Carolyn (Orgs.). Religion and International Law. Leiden; Boston: Martinus Nijhoff Publishers, 2004.
For instance, the Salamanca School was pivotal to conciliate the sacred and profane in the European expansion to unchartered territories. It was necessary for this intentional project to use reason and religion as the required ideology for justification of the new international order, especially because the boundaries of the public and private dimensions became even more blurred during the colonial period, which was revived in several opportunities in the $19^{\text {th }}$ and $20^{\text {th }}$ century. ${ }^{12}$

As such, we observe initially a rupture between academics defending an increasing and incremental secularization in the production of International Law and decision-makers that in practice incorporate religious-based principles to treaties and conventions. This rupture excludes the vital connection between theory and praxis formed by the understanding of the existing reality and the imagination of the possible, both necessary to avoid the contamination of the society of meaningless experiences.

As part of this argument and against some dissenting voices, we argue that the presence of religion in the building process of International Law is, to a certain extent, positive stance, in reality, leading the argument of the inevitable secularization of International Law to what Unger calls the dictatorship of the lack of alternatives. ${ }^{13}$ As stated by Elder Wilford W. Andersen, religion and politics (which includes the formation of law) "[...] are most successful and most effective when they protect and encourage one another." ${ }^{\prime 14}$ As stated by Janis \& Evans:

$[\ldots]$ both religion and international law are essentially dialogue; both seek to prove the orientation of knowledge and a greater realization of the meaning of life. In a sense, the whole concept and practice of global order presuppose a moral and teleological viewpoint that is essentially religious. ${ }^{15}$

12 ANDERSON, Perry. The Ends of History. [s.l.]: Verso Books, 1998.

13 UNGER, Roberto Mangabeira. Depois do Colonialismo Mental. São Paulo-SP: Autonomia Literária, 2018.

14 In https://www.lds.org/ensign/2015/07/religion-andgovernment?lang=eng. Last access: August 30, 2018.

15 JANIS, Mark W.; EVANS, Carolyn (Orgs.). Religion and International Law. Leiden; Boston: Martinus Nijhoff Publishers, 2004. P.151. 


\section{THE CONSTRUCTION OF THE INTERNATIONAL SOCIAL REALITY - INTERNATIONAL LAW AND RELIGION HISTORICAL AND INSTRUMENTAL APPROACHES AND RESISTANCE}

\subsection{Summa-divisio? International Law and Religion as part of the social reality}

Brute and institutional facts make the world we live in according to Searle. ${ }^{16}$ The last category depends on human institutions for their existence, which both International Law and Religion fall into, although in different realms: reason and metaphysics. These realms (altogether with others as important as) provide the objective reality in which society is built, thus, a place for a man to inhabit with some sense of stability. ${ }^{17}$ Therefore, both dimensions are heteronomous organizations and transcendental political entities that connect societies. ${ }^{18}$

As such, the paradigm of the secularization as a phenomenon that brings about the decline of religion in the public arena is no longer sustainable due to empirical evidence. ${ }^{19}$ The practice of diplomacy and politics presents a clear intermingle between Religion and International law to the level of their respective ontology. There are two disregarded premises in this relation, which according to Dark:

\footnotetext{
The first is that religious factors can affect human decision-making and actions. So, when individuals change their religious beliefs, this might be expected to have some effect on their decisions and actions. The second premise is that, as all states, nations and other organizations taking part in world politics are comprised of people, then those people's religious beliefs and affiliations may affect their decisions and actions. From this it also follows that religious change can, although need not always, both help shape (and bring about) change in the decisions and actions of actors in world politics. ${ }^{20}$
}

16 SEARLE, John R. The Construction of Social Reality. New York: Free Press, 1997.

17 BERGER, Peter L. Social Reality of Religion. First Edition edition. London: Faber \& Faber, 1969.

18 BEAULAC, Stephane. The Westphalian Legal Orthodoxy - Myth or Reality? Rochester, NY: Social Science Research Network, 2000. Retrived from: <https://papers.ssrn.com/abstract=2963316>. Last Access: Sept 7, 2018.

19 BERGER, Peter L. The Many Altars of Modernity: Toward a Paradigm for Religion in a Pluralist Age. Digital original edition. Boston: de Gruyter, 2014; TOYNBEE, Arnold J. A Study of History, Vol. 1: Abridgement of Volumes I-VI. New Ed edition. Oxford: Oxford University Press, 1987.

20 DARK, K. R. (Org.). Religion and International Relations. 2000
This approach sheds light into the assumption adopted by mainstream academic circles in the field of International Law and Relations that religion is an exogenous variable that needs to be isolated from the political phenomena, considering the state as a monolithic actor. These paradigms produce an ethos based on an individual idealism, liberal rationalism, and positivism that does not explain or can hold society any longer as it did in the past: techno-formal models that do not account for society's explanatory variables, which disregards the inseparable connection between theory and praxis. $^{21}$ As such, religion is one of the building blocks of the international society, thus, should integrate debate in foreign policies because as:

\begin{abstract}
Case studies suggest that foreign policy is affected by the religion of statesmen and by the communication made possible by transnational networks of religious believers. Religious councils have been established to make the offices of religion available to intergovernmental organizations concerned with international affairs. If religion is operative in foreign affairs, we should endeavor to understand how it can operate for the good. ${ }^{22}$
\end{abstract}

Empirical stance even shows a causal relationship between Law and Religion, which is an essential part of the foreign policy dimension $f$ the countries but receives resistance from coming into epistemic communities. Oman relating the Mormon ${ }^{23}$ experience with the lawmaking process shows the importance of considering religious matters and vice-versa:

In discussing the interaction between law and
religion, scholars and others often speak as if
religion is a given, a phenomenon exogenous to law.
We then ask how the law reacts to religion, either
regulating it, accommodating it, or perhaps being
controlled by it. Implicit in this view is the sense that
law is the agent reacting to religion. The Mormon
experience, however, provides an example of what
this approach misses. The law not only reacts to

edition. London: Palgrave Macmillan, 2000. P. IX.

21 MORAES, Manoel de. Religion and Critical Theory in Max Horkheimer. e-Theologos, v. 2, n. 2, p. 114-122, 2011. Retrieved from: <https://content.sciendo.com/view/journals/etheo/2/2/ article-p114.xml>. Last Access: Sept 7, 2018; MCCARNEY, Joseph. Routledge Philosophy Guidebook to Hegel on History. London ; New York: Routledge, 2000; BIANCHI, Andrea. International Law Theories: An Inquiry into Different Ways of Thinking. New York, NY: OUP Oxford, 2016.

22 DARK, K. R. (Org.). Religion and International Relations. 2000 edition. London: Palgrave Macmillan, 2000. P. 29.

23 Mormon is how member of The Church of Jesus Crhrist of Latter-Day Saints are known. For a complete account of the beliefs and history of the Church see: https://www.lds.org/?lang=eng. Last access: July 16, 2018. 
religion, but it also shapes it. Religious traditions are not static. They evolve and reinterpret themselves over time in reaction to the world in which religious believers find themselves. Law is one of the factors that can force religious change. The Church's abandonment of polygamy in the face of legal pressure from the United States' government is a dramatic example of this kind of change. Less wellunderstood is the way that law has driven shifts in Mormon theological discourse in the 20th century. Thus, beyond any particular interest it may offer, the story of law and the international expansion of Mormonism since 1945 provides an example of the more general phenomenon of how law precipitates religious change. ${ }^{24}$

Like any other social phenomenon, Religion possesses negative or meaningless experiences that contest reason, science, humanism, and progress, all timeless ideals of the Enlightenment. Academic debates tend to disregard the humanism and progress, both as crucial to Religion as to International Law and focus on the meaningless social events such as religious fundamentalism to draw generalizations about secularization (by meaningless social events I refer to any social experience not embedded with the ideals of Enlightenment). ${ }^{25}$ No matter how far we think that modern democracies moved away from the so-called old ontologies, relying on God is very existential to humankind, even thou not admitted expressly. ${ }^{26}$ For instance, paradigms such as the clash of civilization gain traction in the mainstream academic circles, reverberating into the media causing fear and social unrest. ${ }^{27}$

\subsection{The secularization narrative: "In the beginning, Westphalia created secular states. ${ }^{2} 28$}

The Peace of Westphalia is considered the historical marker for the birth of the modern system of states based on legal equality among them due to the sovereignty principle. Westphalia is part of the Early

24 OMAN, Nathan B. International Legal Experience and the Mormon Theology of the State, 1945-2012. Rochester, NY: Social Science Research Network, 2015. Retrieved from: <https://papers.ssrn. com/abstract=2550931>. Last Access: Sept 7, 2018.

25 CARTER, Jimmy. Religion, The Missing Dimension of Statecraft. 1st edition. New York: Oxford University Press, 1995.

26 CROCKETT, Professor and Director of Religious Studies Clayton. Religion in a Secular World: Violence, Politics, Terror. Charlottesville: University of Virginia Press, 2006.

27 BAUMAN, Zygmunt. Liquid Fear. Edição: 1. Cambridge ; Malden, MA: Polity Press, 2006.

28 Paraphrasing Genesis 1:1. In https://www.lds.org/languages/ eng/content/scriptures/ot/gen/1. Last access: September 12,2018.
Enlightenment movement, which ended the Third Years War, making clear that no religion should be a casus belli. However, the religious intolerance continued afterward, which according to Israel:

The profound spiritual crisis which ensued after
1650 was partly caused then by an exacerbated but
wholly unresolved schism between Catholicism
and Protestantism (sometimes nuanced by a
growing awareness of the history and doctrines
of the eastern churches), but it was due also to the
growing fragmentation of the Protestant churches
themselves.

From Westphalia to our days one thing is clear about the conflicts between the 'supra-structures' of Religion and International Law: [...] religion precedes secularism which precedes but also pervades international law-one of secularism's many façades. ${ }^{30}$ To that effect, the Bible presents the story of the Tower of Babel, among other accounts, as one of the traces in the history of the formation of International Law for Jews and Christians. ${ }^{31}$

As should be evident in this paper, the debates over Religion, Secularism, and International Law confines to the Christianity dimension, which since the Westphalia are inseparable and excluding in nature. As suggested by Drinan in the book Can God and Caesar Coexist?: Balancing Religious Freedom and International Law, that might explain why the United Nations never sponsored a legally binding instrument to protect religious freedom as it has been with other minorities. ${ }^{32}$

Upon recognition of the intermingle relation of Christianity and International Law in the postWestphalian phase is essential to understand how was forged the foreign policy in a Weberian track along history. In the sunrise of Westphalia, religious matters were still salient in politics in Europe and served well the new sovereign states to justify the push to colonize

29 ISRAEL, Jonathan I. Enlightenment Contested: Philosophy, Modernity, and the Emancipation of Man 1670-1752. [s.1.]: Oxford University Press, 2006. Retrived from: <http://www.oxfordscholarship.com/view/10.1093/acprof:oso/9780199279227.001.0001/ acprof-9780199279227>. Last Access: Sept 17, 2018. P. 63. 30 CLARK, Martin. The Oxford Handbook of the Theory of International Law. Oxford, United Kingdom: OUP Oxford, 2016. P. 923.

31 PAZ, Reut Yael. A Gateway between a Distant God and a Cruel World: The Contribution of Jewish German-Speaking Scholars to International Law. Leiden ; Boston: Martinus Nijhoff, 2012.

32 DRINAN, Robert F. Can God and Caesar Coexist?: Balancing Religious Freedom and International Law. First Edition edition. New Haven: Yale University Press, 2004. 
Latin America, much of Asia, and, later, Africa. ${ }^{33} 34$

The great effort for states in entering into a new era in which sovereignty was to consolidate and regulate the competing exercise of power in both internal and international dimensions. For Philpott, Westphalia represented the emergence of "[...] a system of sovereign states. Through colonial independence, this system became global. But states are not the only possible forms of authority, and they do not have to be the ultimate sovereign entity." 35

Therefore, as the result of the false Westphalian presumption of the separation between religion and political affairs, European scholars in the $18^{\text {th }}$ and $19^{\text {th }}$ centuries started to focus on the use of rationality, reason, and scientific knowledge to push away the past processes of knowledge production linked to tradition and religion. ${ }^{36}$ As such, Westphalia represented the initial push to incorporate the first wave of Enlightenment assumptions into International Law and Relations. ${ }^{37}$ To that end:

One of the most obvious ways in which secularization has affected the man in the street is as a 'crisis of credibility' in religion. Put differently; secularization has resulted in a widespread collapse of the plausibility of traditional religious definitions of reality. ${ }^{38}$

33 KALMO, Hent; SKINNER, Quentin (Orgs.). Sovereignty in Fragments: The Past, Present and Future of a Contested Concept. Reprint edition. Cambridge: Cambridge University Press, 2014; BEAULAC, Stephane. The Westphalian Legal Orthodoxy - Myth or Reality? Rochester, NY: Social Science Research Network, 2000. Retrived from: $<$ https: / papers.ssrn.com/abstract $=2963316>$. Last Access: Sept 7, 2018; CASANOVA, José. Religion, European secular identities, and European integration. Religion in an Expanding Europe. Retrieved from: $</$ core/books/religion-in-an-expanding-europe/religion-european-secular-identities-and-european-integration/22E52E5F8EE4E DBA2CCA591B96C2C03D>. Last Access: Sept 7, 2018.

34 For a full acount: LESAFFER, R. (ED.). Peace Treaties and International Law in European History: From the Late Middle Ages to World War One. 1 edition ed. Cambridge: Cambridge University Press, 2008.

35 PHILPOTT, Daniel. Revolutions in Sovereignty: How Ideas Shaped Modern International Relations. First Edition edition. Princeton N.J: Princeton University Press, 2001. P. 11.

36 PHILPOTT, Daniel. Revolutions in Sovereignty: How Ideas Shaped Modern International Relations. First Edition edition. Princeton N.J: Princeton University Press, 2001.

37 SCHWARZ, Tanya B.; LYNCH, Cecelia. Religion in International Relations. Oxford Research Encyclopedia of Politics, 2016. Retrieved from: <http://politics.oxfordre.com/view/10.1093/acrefore/9780190228637.001.0001/acrefore-9780190228637-e-122>. Last Access: Sept 7, 2018; LESAFFER, Randall (Org.). Peace Treaties and International Law in European History: From the Late Middle Ages to World War One. 1 edition. Cambridge: Cambridge University Press, 2008.

38 BERGER, Peter L. Social Reality of Religion. First Edition edition. London: Faber \& Faber, 1969. P.6.
However, in the political circles, the justification for the expansion to other territories and domination of the savages found in religion a safe harbor, counting on with several scholars with a profound sense of religiosity. The secularization narrative as absorbed and reproduced by elites by no means meant to exclude religion entirely from political affairs but to secularize versions of the Christian eschatology to a political end. ${ }^{39}$ This is perceived, for instance, during the $1950 \mathrm{~s}$ to 1970s in the United States in which the Spanish colonial expansion was revived to provide examples of protection of rights. One example of the literature of this period is the article The Spanish Struggle for Justice in the Conquest of America by Lewis Hanke, which points out to the good intentions of the Spanish crown and the virtues of the legal contributions of Francisco de Vitoria and Bartolomé de Las Casas.

While the narrative of secularization becomes more entrenched in the mindset of European elites, practical concerns regarding the formal annexation of uncharted territories and the activities of preachers, traders, adventurers, and warriors in the New Worlds becomes a "thorn in the flesh." It was necessary to conciliate thru the rules of International Law profane activity of trade with the spiritual exercise of proselytism, or in other words, resume the summa-divisio debate originally from Roman law. ${ }^{40}$ Therefore, from the inception of modern International Law, Religion contributed entropically to the stability of the internal structures of the Jus Gentium or in other words according to the Weber-Fechner Law - "perceived change in stimuli is proportional to the initial stimuli." ${ }^{41}$

Considering that International Law was and has been instrumental to the process of imperial and colonial expansions, as it [...] has always served the interests of dominant social forces and States in international relations

39 LÖWITH, Karl. Meaning in History: The Theological Implications of the Philosophy of History. Chicago; London: The University of Chicago Press, 1957.

40 CHANDA, Nayan. Bound Together: How Traders, Preachers, Adventurers, and Warriors Shaped Globalization. 1 edition. New Haven: Yale University Press, 2007; KOSKENNIEMI, Martti. EMPIRE AND INTERNATIONAL LAW: THE REAL SPANISH CONTRIBUTION. University of Toronto Law Journal, v. 61, n. 1, p. 1-36, 2011. Retrieved from: <https://utpjournals.press/doi/10.3138/ utlj.61.1.001>. Last access: September 19, 2018.

41 To a complete overview of the complex adptive systems see: NICOLIS, G.; NOCOLIS, G.; PRIGOGINE, I. Exploring Complexity: An Introduction. F First Edition edition ed. New York: St. Martin's Press, 1989. 
according to Chimni, it was necessary to accommodate the encounter of both sub-systems of the international system formed by the Peace of Westphalia: religion and law. It was necessary to provide a device to smooth the irritation provided by the encounter of these open subsystems. ${ }^{42}$

The scholars of the so-called Salamanca School provided the rational and spiritual accommodation for the practical issues the European were facing in the encounter with natives and new territories ready to be explored, especially considering that conquers was acting (or committing sins) under the auspices of the Spanish crown. ${ }^{43}$ Reut Yael Paz commenting on the works of Salamanca School attributes the success of the reconfiguration of the public/private to the way scholars relied on a religious formula to connect the general tenets of religion and law to the particular demands that the expansionist wave brought. ${ }^{44}$ Their view of International Law is laid down in the next part of the paper, along with an exposition on how the ideas developed by them are resilient to this day in modern International Law.

\subsection{The origins of International Law - religious dimension}

The best graphical representation of the relation between religion and international law from inception to nowadays is the Mobius Ribbon. The ribbon is described as a surface with only one side (when embedded in three-dimensional Euclidean space) and only one boundary, having the mathematical property of being unorientable, thus, there is no way to find the beginning or end (such as the infinite symbol) or in which side of the ribbon the observer is looking at. ${ }^{45}$

The observation of traces in the relationship between

42 CHIMNI, B. S. Third World Approaches to International Law: A Manifesto. International Community Law Review, v. 8, n. 1, p. 3-27, 2006. Retrieved from: <http://booksandjournals.brillonline.com/ content/journals/10.1163/187197306779173220>. Last access: September 19, 2018.

43 For a full account of the so-called forfounders of International Law see: Nussbaum, A. (1947). A Concise History Of The Law Of Nations (1st edition). Macmillan Co, NY.

44 CLARK, Martin. The Oxford Handbook of the Theory of International Law. Oxford, United Kingdom: OUP Oxford, 2016.

45 To na overview of the Mobious Ribbon see: PICKOVER, Clifford A. The Möbius Strip: Dr. August Möbius's Marvelous Band in Mathematics, Games, Literature, Art, Technology, and Cosmology. New York: Basic Books, 2007. religion and International Law and Relations in various levels of abstraction and empiricism to nowadays makes necessary an explanatory stance of the history behind it. There is a tendency to isolate the religious dimension in a distant past overcame by the most advanced phases of the Enlightenment at the end of the $19^{\text {th }}$ century, in which secularism reached its peak as stated by Israel: "Hardly anyone today would wish to deny that Cartesianism, and the New Philosophy more generally, with its systematically mechanistic conception of the world had a profoundly innovative and permanently transforming effect on European thought." ${ }^{46}$

This theoretical artifact is an intentional and instrumental political strategy to justify more subtle, and sophisticated forms of imperial domination. The rationale then and now is the same: dealing with nonEuropean peoples while seeking the imperial venture, thus, excluding the indigenous people by the mission civilizatrice and nowadays the existing tradition and metaphysical dimensions that are in contradiction with the universalistic and secularist character of International Law. To Anghie this is a process "[...] to bring the uncivilized/aberrant/violent/backward/ oppressed into the realm of civilization, the universal order governed by (European) international law". ${ }^{47}$

In this turmoil of social transformation, a mixture of conflicting interests, and competition between Christianities, the formation of International Law takes shape. Imperial and the missionary impetus takes place under the auspices of the sovereign state ${ }^{48}$ that with the [...] discovery of the New World, the Catholic Kings accepted a perpetual obligation of evangelization... This need was satisfied by the bull Universalis Ecclesiae, which gave the crown the privileges of founding churches and presenting all persons for an ecclesiastical appointment. ${ }^{49}$

46 ISRAEL, Jonathan I. Enlightenment Contested: Philosophy, Modernity, and the Emancipation of Man 1670-1752. [s.1.]: Oxford University Press, 2006. Retrieved from: <http://www.oxfordscholarship.com/view/10.1093/acprof:oso/9780199279227.001.0001/ acprof-9780199279227>. Last access: September 17, 2018. P. 409.

47 ANGHIE, Antony. Imperialism, Sovereignty and the Making of International Law. 1 edition. Cambridge, UK ; New York: Cambridge University Press, 2007.p.346.

4819 Go ye therefore, and teach all nations, baptizing them in the name of the Father, and of the Son, and of the Holy Ghost: 20 Teaching them to observe all things whatsoever I have commanded you: and, lo, I am with you alway, even unto the end of the world. Amen (Mathews 28: 19-20)In https://www.lds.org/scriptures/nt/matt/28?lang=eng. Last access: Sept 21, 2018.

49 PADDEN, Robert Charles. The Ordenanza del Patronazgo, 1574: 
To Clark commenting on the arrangements between state and church stated that [...] Christian and Eurocentric character of international law remains a tool of both subjugation and liberation of the 'Other. ${ }^{50}$ As such, religion in the first stage of formation of the international system serves the excluding temporal and spiritual of states:

As Ferdinand and Isabella consolidated their kingdoms and pressed to the south, Catholicism became synonymous with the new nationalism and Mohammedanism, and Judaism were crushed beneath its weight. In this unity of national and religious sentiment it was inevitable that the Church and the Holy Office should become quasi-political agencies of the crown, and so it came to pass that secular churchmen became recognized as civil servants. $^{51}$

The issue as the venture of exploring unchartered territories starts was the friction caused by the encounter of the colonizers under the mandate of the crown. Most of these men possess a doubtable moral compass, caring on the evangelization mission. Thus, among the issues raised by this encounter was the stand and responsibility of the sovereign before the Church and God is questioned (for instance, the concept of dominium, and war). Francisco de Victoria, due to his theological and legal background was instrumental in developing a legal structure that saved the Christian congregation from losing political power and moral decay. 5253

The strategy was to present the obedience in binary representation: to God and to the one who represents God himself on earth, thus, in a Foucaultian exegesis the obedience became an end to itself and structured as [...] lesser evil way of life, at least since Adam's Fall. ${ }^{54}$ The approach incorporated natural law to both divine and men made law, which allowed men morally flawed to carry on the trading and missionary work as the situation

An Interpretative Essay. The Americas, v. 12, n. 4, p. 333-354, 1956. Retrieved from: <https://www.jstor.org/stable/979082>. Last access: September 13, 2018. P. 334.

50 CLARK, Martin. The Oxford Handbook of the Theory of International Law. Oxford, United Kingdom: OUP Oxford, 2016. P. 928.

51 PADDEN, Robert Charles. The Ordenanza del Patronazgo, 1574: An Interpretative Essay. The Americas, v. 12, n. 4, p. 333-354, 1956. Retrieved from: < https://www.jstor.org/stable/979082>. Last access: September 13, 2018. P. 333-4.

52 CLARK, Martin. The Oxford Handbook of the Theory of International Law. Oxford, United Kingdom: OUP Oxford, 2016.

53 Francisco de Vitoria, Suarez and other theologicians and jusrists formed the so-called Salamanca School.

54 BERNAUER, James. Michel Foucault and Theology: The Politics of Religious Experience. Edição: 1. Aldershot: Routledge, 2004. P.5. presented itself, therefore, discriminating actions as just/lawful and unjust/unlawful in vague language that ultimately would be determined by the courtroom or the confession booth.

Vitoria and Suarez had a profound influence over Hugo Grotius, the most well-known and prestigious founders of international law. ${ }^{55}$ The Spanish Dominicans presented the idea that natural law was established by God himself, which encompass freedom, common property, and peace that should be exercised by men according to reason. Of course, this relationship is problematic, being captured by Grotius in defense of the freedom of navigation and trade that was opposed against Portuguese and Spanish crowns using the concept of the subjective natural law as developed in his work De Jure Praedae.

Also, the practical activity as a lawyer in defending the Deutch crown, the author of De jure belli ac pacis and Mare liberum is scarcely remembered by his theological works such as Ordinum Hollandiae ac westfrisiae pietas, Defensio fidei catholicae de satisfactione christi and De veritate religionis christianae. It is puzzling that the most extensive work of Grotius, the religious one, is overshadowed by part of his derivative work on Vitoria and Suarez, which leads to inferring the intentional production of a legal and political vocabulary that excludes the religious dimension. ${ }^{5657}$

As the Westphalian era of international law and

55 ANGHIE, Antony. Imperialism, Sovereignty and the Making of International Law. 1 edition. Cambridge, UK ; New York: Cambridge University Press, 2007; FASSBENDER, Bardo; PETERS, Anne; PETER, Simone; et al. The Oxford Handbook of the History of International Law. 1 edition. Oxford, United Kingdom: Oxford University Press, 2013.

56 THOMAS. The Intertwining of Law and Theology in the Writings of Grotius. Journal of the History of International Law / Revue d'bistoire du droit international, v. 1, n. 1, p. 61-100, 1999. Retrieved from: $\quad<$ http://booksandjournals.brillonline.com/content/journals/10.1163/15718059920956689>. Last access: September 22, 2018.

57 Thomas (1999, p. 70) presents an example on the religious and law erudition of Grotius: Grotius, however, in Defensio fidei catholicae de satisfactione christi of 1617,42 was to add what one author has called "a really fresh view of the work of Christ" known as the "governmental theory" of the atonement. Grotius emphasises the role of God as governor of the universe rather than God's justice and the need for every misdeed to be brought into judgment. The law which God applies to human beings is a positive law to which God is in no way bound and one which he can alter or abrogate as he pleases. God, as the ruler of the universe, could have forgiven sin without the death of Jesus but had he done so, argues Grotius, he would have undermined the moral order of the universe. Jesus died to illustrate God's hatred of sin, but bis death was a nominal rather than exact equivalent. 
relations becomes the ruling approach over international affairs. The religious roots remained strongly swinging between positivism and natural law paradigms as it fitted the needs for expansion. However, we observe a recrudescent of the secular narrative at the dawn of the $18^{\text {th }}$ century and sunrise of the $19^{\text {th }}$. However, in the practice and development of international law we observe the maintenance of the approach of using the international lawmaking as a tool to legitimize the colonial venture by other means. ${ }^{58}$

\subsection{Modern International Law - religious dimension still present}

In cultural terms, the modern international law might be traced to the formation of the Institut de Droit International in 1873 as part of the liberal internationalization and the wave of imperial expansion led by Great Britain, France, and Germany. Thus, the international law continues to justify the ethos expansionist of the so-called "discrete civilizers," under the Protestant flagship.

Many of the members of the new Institut de Droit International were members of the delegations that attended the Berlin Conference in 1885, in which the European powers distributed the African continent, the ce magnifique gatean Africa as portrayed by king Leopoldo. ${ }^{59}$ As stated by Anghie: "El derecho internacional moderno nasció cuando los impérios liberales giraron hacia la anexación formal de las colônias. Sin embargo su base ideológica se apoya em uma crítica moralista contra el império espanhol". ${ }^{60}$

The great economic prosperity and scientific revolutions at the end of the $18^{\text {th }}$ and $19^{\text {th }}$ centuries, among other factors, push the development of international law to an idealistic era in which the formation of institutions should bring the stability, order, and the universal peace. James Brown Scott, author of the work The Catholic Conception of

58 ISRAEL, Jonathan I. Enlightenment Contested: Philosophy, Modernity, and the Emancipation of Man 1670-1752. [s.l.]: Oxford University Press, 2006. Retrieved from: <http://www.oxfordscholarship.com/view/10.1093/acprof:oso/9780199279227.001.0001/ acprof-9780199279227>. Last access: September 17, 2018.

59 KOSKENNIEMI, Martti. The Gentle Civilizer of Nations: The Rise and Fall of International Law 1870-1960. Cambridge: Cambridge University Press, 2004.

60 ANGHIE, Antony. Imperialismo y Derecho internacional. 1st edition. [s.l.]: Siglo del Hombre, 2016. P.134.
International Law: Francisco de Vitoria, Founder of the Modern Law of Nations, and assistant of the U.S. State Secretary Elihu Root. ${ }^{61}$

The idealistic view observed in the inter-war period and right after the end of Second World War that transformed the Nations League in the United Nations, a more robust international institution than its predecessor came to a halt as a more pessimistic landscape is formed in the world affairs by the beginning of the Cold War. ${ }^{62}$ There was a strong revival of the realist theory in which security is the center for state's survival in a Hobbesian world, thus, pushing religion to the periphery of the debates regarding the theorization of international law although its Christianity matrix was still presenting despite the growing tension by the exclusion of other religious traditions, especially the Islam. As stated by Afsah, this process possesses stressing factors that would lead to September 11 and its nefast consequences afterward:

Napoleon's expedition inflicted severe narcissist wounds on the Islamic self-image which have yet to heal. The 1967 defeat inflicted similar wounds. ... This Arab complex [goes beyond the issue of modern colonialism, it] is based on a strong delusion concerning Europe's usurpation of our right to make history and to lead the world, in a moment of historical lapse, as is sometimes said here. We view the right to world leadership as if it were a divine right, for which God has chosen Arabs and Muslims. Thus, Arab unification is a necessary step to retrieve that right. Arabs and Muslims would Always find it difficult to accept their position on the margins of modem history since they view themselves, consciously or unconsciously, as members of a great nation and the bearers of God's true religion and that God is on their side. ${ }^{63}$

61 FINCH, George A. James Brown Scott, 1866-1943*. American Journal of International Law, v. 38, n. 2, p. 183-217, 1944. Retrieved from: <https://www.cambridge.org/core/journals/ american-journal-of-international-law/article/james-brown-scott18661943/2B8EBDD64E78666AFA3B383729C5883A\#>. Last access: September 29, 2018.

62 CARR, E. H. The Twenty Years' Crisis, 1919-1939: Reissued with a new preface from Michael Cox. 1st ed. 2016 edition. London, United Kingdom: Palgrave Macmillan, 2016.

63 AFSAH, Ebrahim. Contested Universalities of International Law: Islam's Struggle with Modernity. Rochester, NY: Social Science Research Network, 2008. Retrieved from: <https://papers.ssrn.com/abstract $=2373747>$. Last access: September 29, 2018. P. 265-6. 
At the same time, we observe these tensions in the development and practice of international law; the academic debate reveals an exacerbation of the secular identity of international law contrary to its origins and practice, which demonstrates to be inutile as their ontologies are close connected. ${ }^{64}$ However, this tension hits two empirical observations that challenge the unpractical positivist secularism: (1) the idealistic period inter-wars encapsulated several religious principles and ethics in transformation of international law and organizations; (2) the decolonization waves introduced a multiplicity of actors and traditions to the international system that prescribes universality as theorized by international lawyers and scholars; and (3) the post-Cold War presents a proliferation of intra-states conflicts, most of them religion-based that produced spill-over to regional and international level (the Peace Research Institute Oslo-PRIO has mapped 241 conflicts from 1946 to 2004). ${ }^{65}$ Mark Weston Janis pointed out that there is an estimation that almost 220 million people died in the $20^{\text {th }}$ century as a result of ethnic cleansing, which primary cause is religious antagonism. ${ }^{66}$

Mainstream academic circles portray the secular states as the mechanical Enlightenment world, a simpler and more familiar world as theorized by the Realist tradition in which states are (1) monolithic, and the main agents in international relations; (2) concerned only with their survival as there is no superior authority in the international system, which structure is anarchical; and (3) that the state of war is continuous and inevitable. ${ }^{67}$ Also, the claim of the scientific essence of international Law presents an additional obstacle as the "[...] effort have felt that doing law scientifically means keeping religion and morals absolutely out of the discipline". ${ }^{68}$

64 JANIS, Mark Weston. A Sampler of Religious Experiences in International Law. Rochester, NY: Social Science Research Network, 2008. Retrieved from: <https://papers.ssrn.com/abstract=1101749>. Last access: May 21, 2018.

65 In https://www.prio.org/Data/Armed-Conflict/Data-onreligious-cleavages-and-civil-war/. Last access: Sept 21, 2018.

66 In https://www.asil.org/insights/volume/7/issue/13/religion-and-international-law. Last access: Sept 21, 2018.

67 PHILPOTT, Daniel. Revolutions in Sovereignty: How Ideas Shaped Modern International Relations. First Edition edition. Princeton N.J: Princeton University Press, 2001.

68 JANIS, Mark Weston; KENNEDY, David; ARSANJANI, Mahnoush H.; et al. Religion and International Law. Proceedings of the Annual Meeting (American Society of International Law), v. 82, p. 195-220, 1988. Retrieved from: <https://www.jstor.org/stable/25658424>. Last access: September 29, 2018.
In this sense, Savić explains the consequences of this mechanical approach applied to secularism:

Secular states that ban public religiosity have four major issues. First, they forget that religious norms are part of the state's public and legal existence. Second, they are removing religion from the legal system. Third, they do not understand the role of religious concepts and traditions in the lives of their citizens. Fourth, they lose the ability to discourage behavior that is outside the acceptable norm. ${ }^{69}$

The jumps in history in this part of the paper might seem exaggerated to the point of compromising the interior validity and cohesion; however, for the purpose of achieving the research objective, sparse episodes in this history were instrumental to present how the religious background is connected to the modern international law, which in turn is connected to the practice of imperial venture at the same time that in the epistemic community the secularism is prescribed as a matter of making international law more rational and scientific.

In the next part of the article, we should present the encounters of international law and religion from a theoretical and empirical perspective, searching to unfold the (un)practical aspects of the secularism. It is a necessary analytical dimension to identify the ordering principles or the absence thereof vis-a-vis the global and regional insecurity due to religious conflicts.

\subsection{Religious experiences in international law: political and epistemic communities}

Religion and international law are congruent as both are essentially in dialogue seeking to prove orientation of knowledge and greater realization of the meaning of life. There are a few instances in which they are in direct conflicts, such as environmental prescriptions on the prohibition on whaling that might conflict with indigenous religious and traditional practices or to protect the rights of women (for instance, the Convention Against the Elimination of All Forms of Discrimination Against Women) that have been rejected by some Islamic countries.

69 SAVIĆ, Vanja-Ivan. Still Fighting God in the Public Arena: Does Europe Pursue the Separation of Religion and State Too Devoutly or Is It Saying It Does Without Really Meaning It? BYU Law Review, v. 2015, n. 3, p. 679-726, 2015. Retrieved from: <https://digitalcommons. law.byu.edu/lawreview/vol2015/iss3/5>. Last access: September, 21, 2018. P.679. 
However, the positive intermingle by direct or indirect influences are the pattern. For instance, at the global level, the Universal Declaration of Human Rights, the International Covenant on Civil and Political Rights, the Declaration on the Elimination of All Forms of Intolerance and Discrimination Based on Religion or Belief, Convention on the Prevention and Punishment of the Crime of Genocide, and the Convention Relating to the Status of Refugees. At the regional level, the pattern of incorporating religious principles are identical to the international level. As stated by James A. R. Nafziger:

Several examples of specific doctrinal contributions
$\ldots$ may help confirm the creative function of
religious doctrine in the formulation of modern
international law. At a very deep level of significance,
there seem to be certain universal, religious doctrine
in the formulation of modern international law....
For example ... all of the major religions propound
a Golden Rule- treat others as you would like to
be treated - that is the basis of reciprocity ... that
has shaped humanitarian, legal doctrine. ${ }^{70}$

The support of the development of international law by religious institutions might be observed for example in the Society of Friends (Quakers), the Brethren in Christ (Mennonites), the Church of the Brethren, the United Society of Believers in Christ's Second Appearing (Shakers), and the Bahá'í Faith, all agreeing in the central role of peace and the development for global order. $^{71}$ Also, the World Council of Churches (WCC) influenced by Third World churches has been actively pursuing programs to support the rule of international law, such as the Statement on terrorism, counter-terrorism and buman rights of February 23, 2006, which states:

\begin{abstract}
In recent times, acts of terror and some aspects of the so-called "war on terror" have introduced new dimensions of violence. In addition, fundamental international laws and norms, including longestablished standards of human rights, have come under threat. ${ }^{72}$
\end{abstract}

70 JANIS, Mark Weston; KENNEDY, David; ARSANJANI, Mahnoush H.; et al. Religion and International Law. Proceedings of the Annual Meeting (American Society of International Law), v. 82, p. 195-220, 1988. Retrieved from: <https://www.jstor.org/ stable/25658424>. Last access: September 29, 2018. P.2.

71 JANIS, Mark W.; EVANS, Carolyn (Orgs.). Religion and International Law. Leiden; Boston: Martinus Nijhoff Publishers, 2004.

72 In https://www.oikoumene.org/en/resources/documents/ commissions/international-affairs/human-rights-and-impunity/ statement-on-terrorism-counter-terrorism-and-human-rights. Last access: Sept 21, 2018. See also Religions for Peace (https://rfp.org/ act/campaigns/).
Thus, the dialectic feature between international law and religion present positive aspects for both, although each with its ontology and epistemology. Since Westphalia, the conflicts based on religion hasn't stopped as international became more complex by the entrance of new transnational actors and movements, especially by the introduction of decolonized countries, amounting around 200 countries. ${ }^{73}$ However, as declared by Stempel:

"[...] far from being a purely negative factor, religion properly managed has played, and may play, an even more important positive role in diplomacy and conflict resolution. If some religious values strengthen diplomacy, diplomacy also provides tools for managing, perhaps even resolving, religious disagreements and easing religious conflicts. The biggest impediment to this auspicious outcome is lack of knowledge and correct information by all major social groups about religious/diplomatic linkages." ${ }^{74}$

Frequently, academics tend to exclude from debates some aspects that encompass: (1) the faith and beliefs of politicians, statesmen, and diplomats; (2) the belief structures permeating national and international perception and views of reality; (3) the organizational impact of faith issues and religious organization as we state before; and (4) special issues that religion presents for politics, increases diplomat's stock for persuasion and bargaining, which according to Stempel: "The fact that few scholars and perhaps even fewer statesmen, theologians, or media folk are equally knowledgeable in both fields (international politics and religion) could be a scary proposition." ${ }^{75}$

The "danger" pointed out by Stempel is justified as observed in Figure $1 .^{76}$ The bibliographic mapping of international and religion using VOSviewer. ${ }^{77}$

73 JANIS, Mark Weston. A Sampler of Religious Experiences in International Law. Rochester, NY: Social Science Research Network, 2008. Retrieved from: <https://papers.ssrn.com/abstract=1101749>. Last access: May 21, 2018.

74 STEMPEL, John D. Faith and Diplomacy in the International System. Retrieved from: <http://www.uky.edu/ stempel/faith.htm>. Last access: September 30, 2018. P.5.

75 STEMPEL, John D. Faith and Diplomacy in the International System. Retrieved from: <http://www.uky.edu/ stempel/faith.htm>. Last access: September 30, 2018. P.8.

76 STEMPEL, John D. Faith and Diplomacy in the International System. Retrieved from: <http://www.uky.edu/ stempel/faith.htm>. Last access: September 30, 2018.

77 "A map normally includes only one type of link. Also, between any pair of items, there can be no more than one link. Each link has a strength, represented by a positive numerical value. The higher this 
The dataset for analyzing and constructing the map has been constructed using the following parameters: (1) to collect the data is used the Publish or Perish (version 6.34.6288.6798 ${ }^{78}$; (2) the research term is "international law and religion"; (3) years of publication 1945-2018; and (4) Google Scholar as data source. The metrics in the dataset are:

\begin{tabular}{|lrr|}
\hline Metrics & & \\
\hline Citation years: & 73 & $(1945-2018)$ \\
Papers: & & 263 \\
Citations: & & 297 \\
Citations/year: & & $\left({ }^{2}\right.$ count $\left.=4\right)$ \\
Citations/paper: 8.32 & 2065.50 \\
Citations/author: & & 243.12 \\
Papers/author: & & \\
& & \\
\end{tabular}

The bibliographic map shows clusters of related topics to international law and religion. The terms gravitating the clusters present a negative semantic as related to challenges presented by religion to international law and politics (the size of the font indicates the frequency of the term).

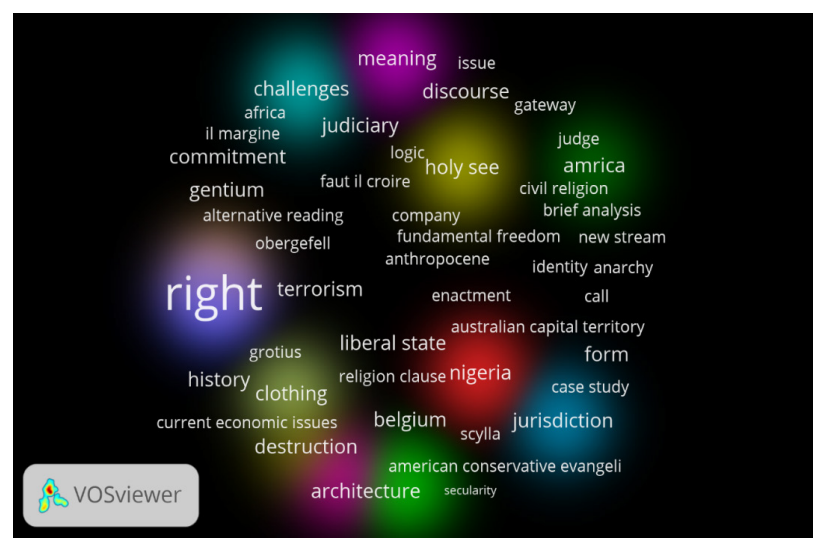

Figure 1

The dimensions of faith and international law and politics have been connected from immemorial time,

value, the stronger the link. The strength of a link may for example indicate the number of cited references two publications have in common (in the case of bibliographic coupling links), the number of publications two researchers have co-authored (in the case of co-authorship links), or the number of publications" In http:// www.vosviewer.com/getting-started\#VOSviewer $\% 20$ manual. Last access: Sept 21, 2018.

78 In https://harzing.com/resources/publish-or-perish. Last access: Sept 21, 2018. which currently there is a search for post-Modern linkages and forms of exploring the empirical and normative aspects of this combination. However, as we observe in the bibliometric map, it is particularly difficult because it cuts across scholarly categories and severely challenges some components of current "scientific" and pseudo-scientific orthodoxy that exacerbates terms and concepts. ${ }^{79}$

\section{Final Remarks}

The connection between international law and religion is compared to two lines traveling thru time in parallel. During history, these two lines are closer than distant to each other, even sometimes so close that appears to be just one line.

Despite the efforts to increase the distance between them due to the scientific and modern international law turn in the $18^{\text {th }}$ century, their ontological and epistemological matrixes difficult the complete separation. For that matter, international law should not be driven by religion but aware of its importance beyond the traditional locus of its production but to local peoples where the effects of legal institutions are felt on a daily basis.

We agree with Savić that "Lawyers must do their part: they must shape the law to fit the religion and culture within the nation," adding to that rationale international lawyers, statesmen, and diplomats as bearers of beliefs and traditions in the personal but also at the communitarian level. ${ }^{80}$

International law from inception has been permeated by religion, sometimes used as part of a domination project, however, despite this warning provided by TWAIL, we observed in our analysis the presence of higher and virtuous principles that are the product of the relation between law and religion.

Fights over religion, as over any dimension in the

79 CLARK, Martin. The Oxford Handbook of the Theory of International Law. Oxford, United Kingdom: OUP Oxford, 2016.

80 SAVIĆ, Vanja-Ivan. Still Fighting God in the Public Arena: Does Europe Pursue the Separation of Religion and State Too Devoutly or Is It Saying It Does Without Really Meaning It? BYU Law Review, v. 2015, n. 3, p. 679-726, 2015. Retrieved from: <https://digitalcommons. law.byu.edu/lawreview/vol2015/iss3/5>. Last access: September, 21, 2018. P.679. 
social arena are inevitable. However, the empirical stance in this article provides a positive and normative view of this relation. As such, as part of the theoretical framework, were identified the phenomenology and rhetoric aspects of this relationship, as well as the unpractical claim of secularism as some voices "preach" nowadays. Therefore, we think that the major contribution in this article is tracing in the chunks of the history of the phenomenological and rhetorical aspects of the encounter of religion with international law and vice-versa.

\section{BibLIOGRAPHY}

AFSAH, Ebrahim. Contested Universalities of International Law: Islam's Struggle with Modernity. Rochester, NY: Social Science Research Network, 2008. Retrieved from: <https://papers.ssrn.com/abstract $=2373747>$. Last access: September 29, 2018.

ANDERSON, Perry. The Ends of History. [s.l.]: Verso Books, 1998.

ANGHIE, Antony. Imperialism, Sovereignty and the Making of International Law. 1 edition. Cambridge, UK ; New York: Cambridge University Press, 2007.

ANGHIE, Antony. Imperialismo y Derecho internacional. 1st edition. [s.l.]: Siglo del Hombre, 2016.

ANGHIE, Antony. The evolution of international law: Colonial and postcolonial realities. Third World Quarterly, v. 27, n. 5, p. 739-753, 2006. Retrieved from: <https://doi.org/10.1080/01436590600780011>. Last access: September 29, 2018.

BAKER, Henry Wager Halleck. Halleck's International Law, or Rules Regulating the Intercourse of States in Peace and War, Vol. 1. [s.1.]: Forgotten Books, 2012.

BARTHES, Roland. Mythologies. Trad. Annette Lavers. New York, NY: Farrar, Straus and Giroux, 1972.

BAUMAN, Zygmunt. Liquid Fear. Edição: 1. Cambridge ; Malden, MA: Polity Press, 2006.

BEAULAC, Stephane. The Westphalian Legal Orthodoxy - Myth or Reality? Rochester, NY: Social Science Research Network, 2000. Retrieved from: $<$ https://papers.ssrn.com/abstract $=2963316>$. Last access: September 7, 2018.
BERGER, Peter L. Social Reality of Religion. First Edition edition. London: Faber \& Faber, 1969.

BERGER, Peter L. The Many Altars of Modernity: Toward a Paradigm for Religion in a Pluralist Age. Digital original edition. Boston: de Gruyter, 2014.

BERNAUER, James. Michel Foucault and Theology: The Politics of Religious Experience. Edição: 1. Aldershot: Routledge, 2004.

BIANCHI, Andrea. International Law Theories: An Inquiry into Different Ways of Thinking. New York, NY: OUP Oxford, 2016.

CAPOCCIA, Giovanni; KELEMEN, R. Daniel. The Study of Critical Junctures: Theory, Narrative, and Counterfactuals in Historical Institutionalism. World Politics, v. 59, n. 3, p. 341-369, 2007. Retrieved from: : <https://www.cambridge.org/core/journals/ world-politics/article/the-study-of-critical-juncturestheory-narrative-and-counterfactuals-in-historicalinstitutionalism/BAAE0860F1F641357C29C9AC72A54758>. Last access: September 6, 2018.

CARR, E. H. The Twenty Years' Crisis, 1919-1939: Reissued with a new preface from Michael Cox. 1st ed. 2016 edition. London, United Kingdom: Palgrave Macmillan, 2016.

CARTER, Jimmy. Religion, The Missing Dimension of Statecraft. 1st edition. New York: Oxford University Press, 1995.

CASANOVA, José. Religion, European secular identities, and European integration. Religion in an Expanding Europe. Retrieved from: </core/books/ religion-in-an-expanding-europe/religion-europeansecular-identities-and-european-integration/22E52E5F 8EE4EDBA2CCA591B96C2C03D>. Last access: September 6, 2018.

CHANDA, Nayan. Bound Together: How Traders, Preachers, Adventurers, and Warriors Shaped Globalization. 1 edition. New Haven: Yale University Press, 2007.

CHIMNI, B. S. Third World Approaches to International Law: A Manifesto. International Community Law Review, v. 8, n. 1,p. 3-27, 2006. Retrieved from: <http://booksandjournals.brillonline.com/ content/journals/10.1163/187197306779173220>. Last access: September 19, 2018. 
CLARK, Martin. The Oxford Handbook of the Theory of International Law. Oxford, United Kingdom: OUP Oxford, 2016.

CROCKETT, Professor and Director of Religious Studies Clayton. Religion in a Secular World: Violence, Politics, Terror. Charlottesville: University of Virginia Press, 2006.

DARK, K. R. (Org.). Religion and International Relations. 2000 edition. London: Palgrave Macmillan, 2000 .

DAVIS, Murray S. "That's Classic!" The Phenomenology and Rhetoric of Successful Social Theories. Philosophy of the Social Sciences, v. 16, n. 3, p. 285301, 1986. Retrieved from: <https://doi.org/10.117 7/004839318601600301>. Last access: September 6, 2018.

DRINAN, Robert F. Can God and Caesar Coexist?: Balancing Religious Freedom and International Law. First Edition edition. New Haven: Yale University Press, 2004.

FASSBENDER, Bardo; PETERS, Anne; PETER, Simone; et al. The Oxford Handbook of the History of International Law. 1 edition. Oxford, United Kingdom: Oxford University Press, 2013.

FINCH, George A. James Brown Scott, 1866-1943*. American Journal of International Law, v. 38, n. 2, p. 183-217, 1944. Retrieved from: <https://www.cambridge.org/core/journals/american-journal-of-international-law/article/james-brown-scott-18661943/2B8E BDD64E78666AFA3B383729C5883A\#>. Last access: September 29, 2018.

HENKIN, Louis; PUGH, Richard Crawford; SCHACHTER, Oscar; et al. International Law Documents: Cases and Materials. 3rd/Supplm edition. St. Paul, Minn: West Group, 1993.

HOLSTI, Kalevi J. Peace and War: Armed Conflicts and International Order, 1648-1989. Cambridge; New York: Cambridge University Press, 1991.

HUMPHREY, John P. On the Foundations of International Law. The American Journal of International Law, v. 39, n. 2, p. 231-243, 1945. Retrieved from: <https://www.jstor.org/stable/2192343>. Last access: September 6, 2018.
ISRAEL, Jonathan I. Enlightenment Contested: Philosophy, Modernity, and the Emancipation of Man 1670-1752. [s.1.]: Oxford University Press, 2006. Retrieved from: <http://www.oxfordscholarship.com/ view/10.1093/acprof:oso/9780199279227.001.0001/ acprof-9780199279227>. Last access: September $17,2018$.

JANIS, Mark W.; EVANS, Carolyn (Orgs.). Religion and International Law. Leiden; Boston: Martinus Nijhoff Publishers, 2004.

JANIS, Mark Weston. A Sampler of Religious Experiences in International Law. Rochester, NY: Social Science Research Network, 2008. Retrieved from: <https://papers.ssrn.com/abstract $=1101749>$. Last access: May 21, 2018.

JANIS, Mark Weston; KENNEDY, David; ARSANJANI, Mahnoush H.; et al. Religion and International Law. Proceedings of the Annual Meeting (American Society of International Law), v. 82, p. 195-220, 1988. Retrieved from: <https://www. jstor.org/stable/25658424>. Last access: September 29, 2018.

KALMO, Hent; SKINNER, Quentin (Orgs.). Sovereignty in Fragments: The Past, Present and Future of a Contested Concept. Reprint edition. Cambridge: Cambridge University Press, 2014.

KOSKENNIEMI, Martti. EMPIRE AND INTERNATIONAL LAW: THE REAL SPANISH CONTRIBUTION. University of Toronto Law Journal, v. 61, n. 1, p. 1-36, 2011. Retrieved from: <https://utpjournals.press/doi/10.3138/ utlj.61.1.001>. Last access: September 19, 2018.

KOSKENNIEMI, Martti. The Gentle Civilizer of Nations: The Rise and Fall of International Law 1870-1960. Cambridge: Cambridge University Press, 2004.

LESAFFER, Randall (Org.). Peace Treaties and International Law in European History: From the Late Middle Ages to World War One. 1 edition. Cambridge: Cambridge University Press, 2008.

LÖWITH, Karl. Meaning in History: The Theological Implications of the Philosophy of History. Chicago; London: The University of Chicago Press, 1957. 
MANTELLI, Gabriel Antonio Silveira; BADIN, Michelle Ratton Sanchez. Repensando O Direito Internacional A Partir Dos Estudos Pós-Coloniais E Decoloniais.Prim@ Facie - Direito, História e Política, v. 17, n. 34, p. 01-33, 2018. Retrieved from: <http:// www.periodicos.ufpb.br/ojs2/index.php/primafacie/ article/view/35667>. Last access: September 19, 2018.

MCCARNEY, Joseph. Routledge Philosophy Guidebook to Hegel on History. London; New York: Routledge, 2000.

MCSWEENEY, John. Foucault and Theology. Foucault Studies, v. 0, n. 2, p. 117-144, 2005. Retrieved from: $<$ https://rauli.cbs.dk/index.php/foucault-studies/ article/view/863>. Last access: September 19, 2018.

MORAES, Manoel de. Religion and Critical Theory in Max Horkheimer. e-Theologos, v. 2, n. 2, p. 114 122, 2011. Retrieved from: <https://content.sciendo. $\mathrm{com} / \mathrm{view} /$ journals/etheo/2/2/article-p114.xml>. Last access: September 12, 2018.

NICOLIS, Gregoire; NOCOLIS, G.; PRIGOGINE, Ilya. Exploring Complexity: An Introduction. F First Edition edition. New York: St. Martin's Press, 1989.

NIEBUHR, Reinhold; WEST, Cornel. Moral Man and Immoral Society: A Study in Ethics and Politics. 2 edition. Louisville, KY: Westminster John Knox Press, 2013.

NIETHAMMER, Lutz. Posthistoire: Has History Come to an End? Trad. Patrick Camiller. London: Verso, 1994.

NUSSBAUM, Arthur. A Concise History Of The Law Of Nations. 1st edition. [s.l.]: Macmillan Co, NY, 1947.

OMAN, Nathan B. International Legal Experience and the Mormon Theology of the State, 1945-2012. Rochester, NY: Social Science Research Network, 2015. Retrieved from: <https://papers.ssrn.com/ abstract $=2550931>$. Last access: April 30, 2018.

PADDEN, Robert Charles. The Ordenanza del Patronazgo, 1574: An Interpretative Essay. The Americas, v. 12, n. 4, p. 333-354, 1956. Retrieved from: $<$ https://www.jstor.org/stable/979082>. Last access: September 13, 2018.

PAZ, Reut Yael. A Gateway between a Distant God and a Cruel World: The Contribution of Jewish German-Speaking Scholars to International Law. Leiden ; Boston: Martinus Nijhoff, 2012.
PHILPOTT, Daniel. Revolutions in Sovereignty: How Ideas Shaped Modern International Relations. First Edition edition. Princeton N.J: Princeton University Press, 2001.

PINKER, Steven. Enlightenment Now: The Case for Reason, Science, Humanism, and Progress. S.l.: Penguin, 2019.

SAVIĆ, Vanja-Ivan. Still Fighting God in the Public Arena: Does Europe Pursue the Separation of Religion and State Too Devoutly or Is It Saying It Does Without Really Meaning It? BYU Law Review, v. 2015, n. 3, p. 679-726, 2015. Retrieved from: $<$ https://digitalcommons.law.byu.edu/lawreview/ vol2015/iss3/5>. Last access: September, 21, 2018.

SCHWARZ, Tanya B.; LYNCH, Cecelia. Religion in International Relations. Oxford Research Encyclopedia of Politics, 2016. Retrieved from: <http://politics.oxfordre.com/view/10.1093/ acrefore/9780190228637.001.0001/acrefore9780190228637-e-122>. Last access: September 6, 2018.

SEARLE, John R. The Construction of Social Reality. New York: Free Press, 1997.

STEMPEL, John D. Faith and Diplomacy in the International System. Retrieved from: <http://www. uky.edu/ stempel/faith.htm>. Last access: September 30, 2018.

THOMAS. The Intertwining of Law and Theology in the Writings of Grotius. Journal of the History of International Law / Revue d'histoire du droit international, v. 1, n. 1, p. 61-100, 1999. Retrieved from: <http://booksandjournals.brillonline.com/content/ journals/10.1163/15718059920956689>. Last access: September 22, 2018.

TOYNBEE, Arnold J. A Study of History, Vol. 1: Abridgement of Volumes I-VI. New Ed edition. Oxford: Oxford University Press, 1987.

UNGER, Roberto Mangabeira. Depois do Colonialismo Mental. São Paulo-SP: Autonomia Literária, 2018.

VAGTS, Alfred; VAGTS, Detlev F. The Balance of Power in International Law: A History of an Idea. American Journal of International Law, v. 73, n. 4, p. 555-580, 1979. Retrieved from: <https://www. cambridge.org/core/journals/american-journal-of- 
international-law/article/div-classtitlethe-balance-ofpower-in-international-law-a-history-of-an-ideadiv/0E 85B738554D09B6FBD6267799F414B2>. Last access: May 19, 2018.

VAN ECK, Nees Jan; WALTMAN, Ludo. Visualizing Bibliometric Networks. In: DING, Ying;
ROUSSEAU, Ronald; WOLFRAM, Dietmar (Orgs.). Measuring Scholarly Impact: Methods and Practice. Cham: Springer International Publishing, 2014, p. 285320. Retrieved from: <https://doi.org/10.1007/9783-319-10377-8_13>. Last access: September 30, 2018. 
Para publicar na Revista de Direito Internacional, acesse o endereço eletrônico www.rdi.uniceub.br ou www.brazilianjournal.org.

Observe as normas de publicação, para facilitar e agilizar o trabalho de edição. 